\title{
Metapragmatics and genre: Connecting the strands
}

\section{Evgeni N. MOLODYCHENKO ${ }^{1}$ and Jürgen SPITZMÜLLER ${ }^{2}$}

${ }^{1}$ Higher School of Economics National Research University

St. Petersburg, Russia

${ }^{2}$ University of Vienna

Vienna, Austria

\begin{abstract}
Genre analysis involves at least a 'foray' into the social/contextual dimension framing genreexemplars. One way to explore this dimension is drawing on the concept of metapragmatics, which is primarily associated with (American) linguistic anthropology. However, with a few exceptions, genre studies have not consistently operationalized metapragmatics, either theoretically or practically. The purpose of this article is, therefore, to explore one possible angle of such operationalization by means of studying discourse fragments reflecting on fragments of (these very or other) discourses (so-called metapragmatic discourses) vis-à-vis any generic properties of the reflected discourse. Specifically, we analyzed comments sections for a number of YouTube videos exemplifying several lifestyle genres. The results indicate that generic references can range from simply using a generic label to refer to the discourse in question (as a token of a certain type/genre) to actually discussing the generic characteristics of the genre it instantiates, as well as projecting certain (generic) metapragmatic stances. Another observation is that different wordings used by the discourse community to refer to generic models can be, as it were, 'proper' generic labels, but they can also be words and phrases that would hardly qualify as proper names of genres from an analyst's point of view. Both these 'proper' and other - 'genre-like' - labels are also often used in conjunction with or are replaced by other ways of metapragmatically referring to what the speaker 'does' or even what they 'are' in/by dint of using the discourse in question. This suggests that any generic labels or cues are just part of a large pool of other possible metapragmatic meanings, knowledge, and ideologies circulating in discourse communities. More broadly, the results may indicate that genre studies should see genre as an even less 'stabilized' entity because what a genre is depends on what people who actually use it 'make of it', as well as augment their standard toolkits with methods aimed at exploring metapragmatic discourse.
\end{abstract}

Keywords: metapragmatics, metapragmatic discourse, genre, genre cues, discourse community, contextualization

\section{For citation:}

Molodychenko, Evgeni N. \& Jürgen Spitzmüller. 2021. Metapragmatics and genre: Connecting the strands. Russian Journal of Linguistics 25 (1). 89-104. DOI: 10.22363/2687-0088-202125-1-89-104 


\title{
Метапрагматика и жанр: объединяя подходы
}

\author{
Е.Н. МОЛОДЫЧЕНКО'1, Ю. ШПИЦМЮЛЛЕР² \\ ${ }^{1}$ Национальный исследовательский университет «Высшая школа экономики» \\ Санкт-Петербург, Россия \\ ${ }^{2}$ Венский университет \\ Вена, Австрия
}

\begin{abstract}
Аннотация
Исследование жанра в той или иной мере предполагает изучение контекста. Одним из возможных подходов к изучению такового является обращение к метапрагаматике - понятию, преимущественно развивавшемуся в американской лингвистической антропологии. За исключением некоторых отдельных работ, данное понятие не было сколько-либо последовательно операционализировано в жанроведении. Цель настоящей статьи - обозначить один из возможных вариантов такой операционализации, заключающийся в анализе так называемых метапрагматических дискурсов, то есть дискурсов или их фрагментов, рефлексивно отражающих собственную прагматику или прагматику внешних по отношению к ним дискурсов в разрезе рефлексий, связанных с жанровой спецификой рефлексируемых дискурсов. Материалом исследования послужили пользовательские комментарии к нескольким видео на платформе YouTube в разных жанрах лайфстайл-дискурса. В результате анализа демонстрируется, что фигурирующие в метапрагматических дискурсах жанровые рефлексии могут иметь различную форму - от использования «жанровых ярлыков» для отсылки к рефлексируемому дискурсу (как экземпляру определенного жанра) до обсуждений жанровых особенностей экземпляра и/или жанра в целом, а также часто сопровождаются актуализацией оценочной позиции, занимаемой коммуникантом/-ами по отношению к жанру. Использование собственно жанровых ярлыков имеет определенную специфику: для именования жанра коммуниканты могут оперировать как «правильными» жанровыми ярлыками, т.е. такими, которые являются более-менее устоявшимися именами жанров или могли бы потенциально к ним быть причислены, так и более «свободными» и «неточными» формулировками. Наблюдение за использованием ярлыков обоих типов, а также иных способов актуализации жанровых рефлексий демонстрирует, что все они являются лишь частью массива средств, используемых коммуникантами для рефлексий в разрезе того, что автор дискурса «делает», а также того, «кем» он в данном коммуникативном событии (или путем его реализации) «предстает». Полученные результаты подчеркивают то, что в случае с жанроведением одним из аспектов изучения некоторого жанра следует рассматривать исследование того, каким образом этот жанр «видят» реальные коммуниканты, рутинно с ним взаимодействующие, и то, что работа с метапрагматическими дискурсами могла бы стать значимым дополнением к стандартному жанроведческому инструментарию.
\end{abstract}

Keywords: метапрагматика, метапрагматический дискурс, жанр, дискурсивное сообщество, контекстуализация

\section{Для цитирования:}

Molodychenko E.N., Spitzmüller J. Metapragmatics and genre: Connecting the strands. Russian Journal of Linguistics. 2021. Vol. 25. № 1. P. 89-104. DOI: 10.22363/2687-00882021-25-1-89-104

\section{Introduction}

As is well known, genre studies have always been faced with analytical challenges. To name just a few, there is the traditional 'form vs function' dilemma 
(see e. g. Devitt 2009, Giltrow 2010), with the issues of tackling the linguistic variation that different instances of (even) one and the same genre may exhibit (see e. g. Rose 2012, Swales 1990: 49-52), the issues of genre hybridity (see e. g. Fairclough 2003: 69), and of genres 'never actually being stabilized' (see e. g. Devitt 2009: 39) gravitating towards the 'form' end of the spectrum, and the issues of the disparate ways actors can actually engage with (even) one and the same genre (see e.g. Askehave \& Swales 2001; Swales 1993) gravitating towards the 'function' end. There is also the "well-known quagmire" (Lee 2001: 41) of distinguishing between genres and a plethora of other terms like text-type, register, and style (Giltrow 2010; Lee 2001). And finally, there has always been the issue of the 'form' not really being restricted to the linguistic form per se, but rather being an intricate combination of various modalities - an issue which could be somewhat backgrounded in case of (and in the age of) media often relying on (simple) printed text (see, however, Hiippala 2017) but became more a matter of concern with the advent of digital genres (Askehave \& Nielsen 2005, Giltrow \& Stein 2009), often relying on arguably a wider range of modalities which digital media seem to make more 'readily available'. These and other points of contention are partly reflected in a possible definition of the genre that can be seen as a social action (with all the complexities involved in theorizing said action) calling for a certain - more or less stable/fixed - discursive form ${ }^{1}$ (with all the complexities involved in theorizing said form; cf. Fairclough 2003: 65; Miller 1984, Swales 1990: 45).

Apart from making the multimodal aspect of generic forms harder to ignore, digital media have also introduced a wider range of affordances, the availability of which on certain platforms has, in its turn, facilitated the transformation of participatory frameworks and, consequently, the role audiences play in producing and contextualizing discourses (Boyd 2014, Szabla \& Blommaert 2018). This kind of participation has also arguably resulted in increased 'visibility' of discourse referencing, as it were, the pragmatics of other discourses. The former is sometimes referred to as metapragmatic discourse (Silverstein 1993, Spitzmüller 2015). Although genre studies have been addressing the metapragmatic dimension at least since the term 'discourse community' was introduced (Swales 1990), these studies in our opinion could benefit from a more systematic operationalization of metapragmatics and a more targeted exploration of metapragmatic discourses (see also Briggs 1993, Briggs \& Bauman 1992, Gnezdilova 2018, Spitzmüller 2013: 237-280).

The purpose of this paper is, therefore, to further theoretically and analytically integrate metapragmatics into genre analysis. From a more practical standpoint, the purpose is to explore several instances of metapragmatic discourse vis-à-vis possible generic references used by the speakers. With this aim in mind, seven YouTube videos and their accompanying comments have been analyzed. The

${ }^{1}$ This, of course, could also be reversed, as we may also think of discursive forms regimenting, as soon as they are deployed, the communicative episode as a certain type of social action, calling for a certain type of social relations between the actors to obtain or be 'constructed'. 
videos instantiate several genres (that may be) used by typical contemporary lifestyle YouTube channels (Molodychenko 2019), which can, in turn, be seen as part of a wider phenomenon of lifestyle media (see e.g. Bell \& Hollows 2005).

\section{Genre cues in emergent metapragmatic models of discourse}

\subsection{Pragmatics and text-level indexicality}

According to Silverstein (1987), there are two functions of language which linguists have traditionally referred to. The first one, which is strongly associated with structuralism, posits that what a stretch of discourse means as a whole can be explained by the sum of its constituent (segmentable) elements. Each such element can be said to be drawing its meaning from its position in the system of language (Blommaert 2015: 9). However, there has also been another longstanding tradition which rather sees stretches of discourse in terms of what they 'do' socially. This goes as far back as ancient rhetoric and, in more recent times, can be exemplified with what has been done in linguistic anthropology and within "much of what goes on under the name of "pragmatics"" (Silverstein 1987: 24). As we shall elaborate in what follows, this second tradition does not go well with the first one methodically.

In most general terms, the main attempt of a pragmatically oriented inquiry is to shed light on the relation of language (or discourse) and context. This relationship can be expanded in two directions: pragmatic inquiry can try to reveal how context shapes discourse (context-boundedness of discourse) or it can try to reveal how discourse shapes context (contextualization by discourse). In order to understand what a discourse 'does' socially (i.e., in and to context), and how it does that, both directions, and the bi-directionality of pragmatic processes, need to be considered (Silverstein 2003: 195). As opposed to formal matters or semantics, the how part of the equation cannot be resolved easily by the structuralist segmentation and classification approach. Even though it is controversial (and most strongly challenged by proponents of Semantic Holism; cf. Jackman 2017), linguistics has developed elaborated means to segment the overall flow of discourse semantically and to analyze (i.e., classify) what each such segmentable part contributes to the whole in terms of (referential) meanings (Silverstein 1976). This was done, for instance, using a sentence theory informed by propositional calculus (Silverstein 1987: 18-23), or with an arguably more socially oriented analytical tool such as Systemic Functional Linguistics (primarily in terms of the ideational metafunction; see Halliday \& Matthiessen 2004). For pragmatic analysis, such atomistic approaches have proven significantly less satisfying.

The reasons for this are manifold. First and foremost, potentially segmentable elements of discourse cannot be assigned to specific (decontextualized) pragmatic functions in the way segmentable elements can be assigned to specific (decontextualized) semantic (i.e., referential) meanings (considering the caveats above). Their function (or pragmatic meaning, as we might say) emerges through indexical reference to an ever-changing context which can also retrospectively (effectively; Silverstein 2003: 195-196) alter pragmatic meaning over the flow of 
discourse. Second, each segmentable element can simultaneously index different contextual variables (Eckert 2008, Silverstein 1976, Silverstein 1992). And third, the pragmatic function or meaning of elements correlates to the pragmatic function or meaning of co-occurring elements. As Agha notes:

a textual order contains, or conveys, indexical information that is not reducible to the indexical values of any of its parts. To speak of text-level indexicality in this sense is to speak of a wholly emergent type of information that reflexively shapes the construal of behavior while the behavior is still under way. Such text-level indexical effects are completely non-detachable for purposes of construal: They are not preserved under decontextualization. If you isolate a piece from the total textual process that motivates the effect, the semiotic partial thus 'detached' appears to have no property that could explain the text-level effect, no matter how carefully you inspect it! The effect depends on the comparability of co-occurring signs - by criteria of congruence/non-congruence - and therefore vanishes when the sign is isolated and inspected by itself. (Agha 2007: 24; orig. emph.)

These conditions render the aim of classifying decontextualized pragmatic 'types' rather futile.

\subsection{Metapragmatic models and metapragmatic knowledge}

From a pragmatic point of view, meaning is thus not inherent to text but constructed in interaction (see e.g. Chernyavskaya 2020). When engaging in discourse, we build a more or less coherent holistic representation of what goes on (both semantically and pragmatically) in this stretch of discourse based on the combined input of elements signaling semantically ('symbolizing') and pragmatically ('indexing') as well as on our communicative knowledge (Gumperz 1992). Drawing on Agha (2007: 37), we refer to this holistic representation as a metapragmatic model of discourse. This model, in effect, is the realization of Silverstein's metapragmatic function, which "serves to regiment indexicals into interpretable event(s) of such-and-such type that the use of language in interaction constitutes (consists of)" (Silverstein 1993: 37). The metapragmatic model encompasses the metasemantic model, as we follow Silverstein's (1993: 39) proposal to incorporate metasemantics into metapragmatics (see also Verschueren 2000: 442), since "[t] he metapragmatic characterization of speech must constitute a referential event, in which pragmatic norms are the objects of description" (Silverstein 1976: 48). This is also borne out by lay observation that whatever the communicative actor is 'doing' through/in discourse also includes, but is in no way restricted to, what 'information' they are trying to 'relay' (cf. Blommaert 2015).

In somewhat broader terms, we may also speak of metapragmatics or metapragmatic dimension of language use with reference to the reflexive awareness that speakers normally have as to the various ways language is (being) used (Verschueren 2000). Such metapragmatic awareness - both contextualized and decontextualized (in the form of what we might call metapragmatic knowledge or 
linguistic ideologies) - is analyzable only to the extent that it is materialized in a metapragmatic act of some sort (Agha 2007: 17; Spitzmüller 2015: 129). One of the main modes in which these acts can be materialized is, as it happens, language itself (or, for that matter: speech, writing, or gesture; cf. Auer 1992). Metapragmatic acts range from using an isolated metapragmatic 'label' to refer to a (segment of) discourse, including the cases where the label is used to refer to the very same segment/discourse whose part this label happens to be $^{2}$, to "laying down" a (fullfledged) "denotational text" (Silverstein 1993: 42) referencing the pragmatics of a certain other (segment of) discourse. Denotational texts of this type may be referred to as metapragmatic discourse (Silverstein 1993). Such discourse can become an invaluable source of analytical data if the goal of the project is to explore not so much the meaning potential of a certain discourse in question but rather the various (often conflicting) ways it is being contextualized (perceived, understood, interpreted etc.) by a real group of actors (Spitzmüller 2015: 137-138; Chernyavskaya 2020) or - as we shall call this group below - a discourse community.

\subsection{Genre cues as metapragmatic markers}

One distinct type of what we have referred to as metapragmatic labels are names of genres. Relating a certain (segment of) discourse to a certain genre, explicitly or implicitly (Briggs \& Bauman 1992, Hanks 1987), is, we contend, one of the ways of specifying what a certain segment/discourse (supposedly) 'does' socially or what type of social action it (supposedly) realizes (see/cf. also Fairclough 2003: 64 ff., passim; Miller 1984: 198). Names of genres are thereby one, and only the most explicit, instance of the metapragmatic devices we call genre cues (cf. Spitzmüller 2013: 257-249; the term is borrowed from Androutsopoulos 2001: 20). Genre cues are contextualization cues (sensu Gumperz 1992) that hint to the interpreter what genre a certain segment/text 'belongs' to and hence how it is to be interpreted. As with all contextualization cues, whether this hint is indeed taken up in interpretation depends on the (so far established) context and the interpreter's communicative knowledge. Furthermore, genre cues need not be issued deliberately by the producer of the utterance. On the contrary, it is possible that the interpreter construes cues that run counter to the producer's intention (hence the supposedly's above). The range of potential genre cues is large. Besides genre names, it consists, among other things, of genre-typical (enregistered) phrases and expressions (Gnezdilova 2018), names (Androutsopoulos 2001), and paralingual elements such as phrasing/intonation in speech (Auer 1992), modes of performance (e.g., posture) or (typo)graphic design elements in written discourse (Spitzmüller 2013: 237-280). So, in what follows, when we pick out genre names by way of example, we only look at the most appropriate or "salient" (to use Verschueren's apt term) way of regimenting a segment/discourse metapragmatically. Our scope of analysis thus

${ }^{2}$ One well-known example of such usage are the so-called performative verbs. 
only comprises a fraction of the complex metapragmatic model that communicative actors form in/for, and construe from, contextualized and contextualizing discourse.

For further theorizing and analysis, we draw on the theory and methods of the ESP (English for Specific Purposes) strand of genre analysis, sometimes referred to as Rhetorical-Linguistic Genre Studies (Devitt 2015: 45). It is arguably one of the most seminal schools of genre analysis in Anglo-American academic discourse. As the name would suggest, being a blend of linguistic and rhetoric approaches, the ESP model emphasizes the analysis of the linguistic 'form' as well as what we might call the contextual dimension ('the function'), with two clusters of variables social and cognitive. We will relate these two clusters to metapragmatics in what follows.

In ESP genre analysis ${ }^{3}$, the communicative purpose, which may be seen as a primarily cognitive variable, is the deciding criterion for identifying genres and distinguishing between formally similar genres (Askehave \& Swales 2001, Bhatia 1993: 19-20, Swales 1990: 46). In metapragmatic terms, communicative purpose may be seen as one of the critical variables for generating a (proper $\left.{ }^{4}\right)$ metapragmatic model of discourse, to which both the producer and the recipient will dialogically orient at the stage of discourse production and the stage of reception and 'sensemaking', respectively (cf. Briggs \& Bauman 1992, Hanks 1987). From a metapragmatic perspective, however, it is crucial to add that communicative purpose is not a quality that is inherent to a stretch of discourse. Rather than that, it is ascribed to this stretch by the communicative actors based on their communicative knowledge and their interpretation of genre cues (and thus it is seen as an epistemic variable). Hence, what is construed as communicative purpose might differ among the involved actors.

The primarily social cluster of variables is operationalized in ESP genre analysis as the discourse community - a community that forms around a certain genre or genres (Swales 1990: 24-32, Swales 1993: 694-696). Approaching a discourse community entails addressing reflections that circulate in a group of communicative actors which have something to do with ways genres in question are (supposedly) being used. In metapragmatic terms, we are dealing here with enregistered (Spitzmüller 2015, Agha 2007) genre knowledge (or assumptions), or genre ideologies (Spitzmüller forthc.). To address such knowledge, we do not always have to resort to interviewing the subjects, like the ESP practitioners would indeed do. The understanding of such reflections can instead be informed by specific discourses which discourse communities produce as a reaction to another discourse (or the very discourse they are part of), provided these, in whole or in part, explicate (or even implicate, that is: display) something about the (construed) generic properties of the reflected discourse. Such discourses are, of course, one example of metapragmatic discourse that was discussed above.

\footnotetext{
${ }^{3}$ As well as in many other genre theories.

${ }^{4}$ As we shall soon see, it is actually somewhat problematic to define 'proper'.
} 


\section{Data and analysis}

One of the key contributing factors to the increased visibility and availability of metapragmatic discourse is the change in participation frameworks, which has accompanied the growth of new media platforms like YouTube or Instagram (Boyd 2014; Lehti et al. 2016; Szabla \& Blommaert 2018). What we refer to here specifically is the enormous amount of 'user comments' which is normally found with popular YouTube videos.

The pool of material for the following analysis is comprised by seven videos with their accompanying comments posted on the YouTube channel alpha $\mathrm{m}$. This channel is one instance of new lifestyle media, which have become increasingly popular over the last few years (Andersen \& van Leeuwen 2017; Bell \& Hollows 2005; Bell \& Hollows 2006; Machin \& van Leeuwen 2005; Machin \& van Leeuwen 2007; Molodychenko 2019; Ivanova 2019). The numbering of examples in the analysis is done as per the following list:

(1) 7 Things About Girls I Wish I Knew Sooner! ${ }^{5}$

(2) A Day in The Life of Alpha $M^{6}$;

(3) My New Daily Routine \& Diet (A Day in the Life of Aaron Marino)

24 Hour Vlog ${ }^{7}$;

(4) Losing My Virginity (Brutally Honest Story) ${ }^{8}$;

(5) Losing Everything!';

(6) I'm Done ${ }^{10}$;

(7) Dealing with Coronavirus (COVID-19) ${ }^{11}$;

The method can be best (and succinctly) described, following Fairclough (Fairclough 2003) and Spitzmüller and Warnke (Spitzmüller \& Warnke 2011), as textually oriented discourse analysis.

One of the most widespread generic models invoked on such channels is (an 'upgraded' version) of what Machin and van Leuween a few years ago labeled "hot tips" (Machin \& van Leeuwen 2007: 116-123). Despite the fact that this generic model seems quite ubiquitous (Molodychenko 2019), the actual usage of any generic labels to refer to it or any other reflections on its generic properties are infrequent. Out of first 200 comments under the video (of 1318 total) at the moment we made the 'snapshot' of the web page ${ }^{12}$, the first explicit usage of the

${ }^{5}$ URL: https://www.youtube.com/watch?v=ffVf0_bSAtk (accessed: 28.06.2020).

${ }^{6}$ URL: https://www.youtube.com/watch? $\mathrm{v}=\mathrm{Nl}-9 \mathrm{c} \overline{\mathrm{Y}} 13 \mathrm{np} 8$ (accessed: 28.06 .2020 ).

${ }^{7}$ URL: https://www.youtube.com/watch? $\mathrm{v}=\mathrm{nP} 4 \mathrm{~W}$-Z89Hc (accessed: 28.06.2020).

${ }^{8}$ URL: https://www.youtube.com/watch? $\mathrm{v}=\mathrm{k} 9 \mathrm{Wlsq} \mathrm{dWn0E}$ (accessed: 28.06 .2020 ).

${ }^{9}$ URL: https://www.youtube.com/watch? $\mathrm{v}=\mathrm{m} 5 \mathrm{abiF} 91 \mathrm{LAM}$ (accessed: 28.06.2020).

${ }^{10}$ URL: https://www.youtube.com/watch? $\mathrm{v}=$ WUIpX6ZZ3P4 (accessed: 28.06.2020).

${ }^{11}$ URL: https://www.youtube.com/watch? $\mathrm{v}=$ FSMyVVw2nxw(accessed: 28.06.2020).

${ }^{12}$ As is well-known, such web pages tend to change over time as new comments are added and also possibly rearranged by the YouTube algorithm. Hence, the 'snapshot' metaphor in the description. 
generic/metapragmatic label was seen in comment number 92 (1.1). In the other 108 comments, a metapragmatic label of some kind was used no more than 5-6 times:

(1.1) Uncle Alpha I appreciate all the advice. I wish you were around when I was a teenager $<\ldots>^{13}$

(1.2) Absolutely love these life tips!

(1.3) Call me weak, but the "cute but sassy" tip didn't sit too well with me

(1.4) By the way, you are doing a terrific job giving valuable advice to young (and sometimes older) guys!!!

A possible explanation of such relatively low count of generic references could be the fact that this genre is, as has been stated above, ubiquitous and hence densely enregistered on lifestyle channels ${ }^{14}$ and lifestyle media in general (including written discourse), so communicative actors see no need to give contextualization cues (of this explicit sort) in order to explicate the frame of interpretation. This explanation gets support if we contrast the case with another, where a generic model is evoked that is not so typical for the cannel ${ }^{15}$ (and other channels of the same kind, but arguably not lifestyle media as a whole), namely the vlog genre. One of the comments that contextualizes this generic model is the following:

\section{(2.1) You would be a great daily vlogger}

This comment comes in at number 50 (of 3373 comments overall) at the time of the 'snapshot' and has around 1500 likes, which can be interpreted as an additional indicator of such reflections being popular in the discourse community. The comment elicited several responses, which further supports the claim that such reflections are current in the community:

(2.1.1) would you like to see the same things every video?

(2.1.2) this vlogging is the stupidest idea homo sapiens invented

(2.1.3) Omg I agree with you he would be amazing

It can be also noted in passing that metapragmatic stances (Spitzmüller forthc.) of communicative actors vis-à-vis this genre, and hence genre ideologies, differ drastically, cf.: the stupidest idea vs he would be amazing. Still in passing it can be noted how such comments illustrate that genre references are not restricted to using generic labels such as advice or vlog but also include ideas of generic properties, cf.: see the same things every video.

Metapragmatic/generic labeling is, of course, not only performed by the audience; actors in the commented videos also use metapragmatic self-references. This may be interpreted as an effort to facilitate the formation of the 'proper'

${ }^{13}$ The spelling, punctuation, and formatting of the comments analyzed hereinafter have been slightly modified.

${ }^{14}$ At the time the 'snapshot' of the state of the channel was 'taken', 87 videos of the last 100 invoked the 'hot tips' model.

${ }^{15}$ Three videos out of the last 100 at the time of the 'snapshot'. 
metapragmatic model on the part of the addressees or as an attempt to authenticate (Bucholtz \& Hall 2005: 585-586, Spitzmüller 2015: 130) their own performance. Cf. a standard metapragmatic label $v \log$ that is used in the title of video 3 (see above) as well as a 'less standard' label in the discourse of заменить на: used within the video:

\section{(3) $<\ldots>$ this is gonna be a day-in-the-life type of video $<\ldots>$}

Such usage of the 'less standard' labels also allows us to highlight another observation. Labels such as vlog, advice, and tips may happen to be more or less 'settled on' and also more likely to be 'endorsed' by genre analysts (and indeed are, as we have already seen in case of hot tips). These, however, in our experience with such media, do not accurately reflect what happens in the discourse community as far as metapragmatic references to discourses "as events of such-and-such type" (Silverstein 1993: 37) are concerned. What often happens is that actors would use what may be called genre-like labels and descriptions, of which (3) is an example. This seems to be even more pronounced when the community is faced with a less familiar genre, which may at this point in time neither have a deeply enregistered generic model nor a common name. One such example is an infrequent ${ }^{16}$ but distinct type of video on the channel under scrutiny, which may be called straight talk. Incidentally, the author gives an interesting metapragmatic description at the beginning of one of his videos 'in the genre', which emphasizes the perceived lack of a term but also arguably the 'exigence' (sensu Miller 1984) for the genre and the name to become available soon:

(4) Today's video falls under the category of "why the hell am I telling you this?"

Both the lack and the exigence are emphasized by the discourse community trying (struggling?) to find a feasible 'workaround' to refer to the genre and its properties in the comments, cf.:

(4.1) I love these videos. Sometimes we need to have these conversations!

(4.2) Love the story time, alpha!

(4.3) The fact that he speaks out about his life has my full respect

(5.1) Aaron, you should do more of these personal talks

(5.2) What do I need? I need more jokes or story time from Alpha M.

(6.1) This sounds like an overheard phone conversation on the subway

(6.2) Loved this lesson, my friend. Thank you

(6.3) Thank you for being open and sharing your story

(6.4) Thanks for reaching out. I was relieved to see your video today

As can be seen from these examples, some actors emphasize the semblance of these instances to casual conversation $(5.1,6.1,4.1)$, an autobiographical narrative ${ }^{17}$

${ }^{16}$ Four videos out of the last 100 at the time of the 'snapshot'.

${ }^{17}$ Incidentally, both casual conversation and 'ordinary' narrative are treated as pre-genres by Swales, i. e. they are not 'true' genres (Swales 1990: 58-61). 
(5.2, 6.3, 4.2, 4.3), advice (6.2) and (for lack of a better word) a confession $(6.4,4.3)$. These are instances of what Bolter and Grusin (1999) refer to as remediation.

These examples bring into sharp relief the idea that using generic labels, both the 'proper' ones, which are likely to be endorsed and used by analysts, as well 'genre-like' metapragmatic references of the type exemplified above, represents only a fraction of metapragmatic genre reflection. This is illustrated by the following examples which refer to different other facets of what the actors are 'doing' - or, as it were, 'being' - socially. All these are characteristics of the communicative event, an intricate nexus of (referential) meanings, social actions, and identities, and they also neatly illustrate how metapragmatic stancetaking, genre construal and authentification correlate:

(4.4) This is my favorite video you've ever made, I really dig the honesty

(4.5) Dude, you're straight up dude. Keep up this genuine stuff man

(4.6) <...> it was nice hearing you open up

(5.3) I've got to say these are my favorite videos you do, when it's just you

being yourself, being honest. Sure, the ones where you being "Alpha", teaching us to hit on girls or whatnot, are entertain; these are the ones that are truly Alpha

(5.4) Appreciate your realness with this all man $<\ldots>$

(5.5) Love that this is so real man. Stay positive

(6.5) The guy can share his difficult emotions openly-example of a true alpha

$(6.6)<\ldots>$ this guy stands on his word. He is not the guy who acts on camera,

he is who he is

(6.7) Wow, for the first time I feel like he's being genuine

(6.8) This level of authenticity is so hard to come by. We appreciate you being real with us bro $<\ldots>$

(6.9) I love these videos, they are so honest and raw

(7.1) I love the spiritual side he brings out very smoothly

\section{Conclusion}

New media platforms have drastically transformed the ways audiences can participate in mediated discourses. The analytical toolkits we use to explore genres and discourses should, in our opinion, factor such changes in and, indeed, benefit from them. One way this could be done is upgrading the way we theorize and operationalize the concept of discourse community as used in ESP genre analysis with the help of insights generated in linguistic anthropology, including particularly the framework of metapragmatics. While doing so, we suggest that analyzing a genre should no longer (only) be a dedicated effort on the part of the analyst to meticulously describe specific instances of the genre in question, as genres in discourse are interactional co-constructions. Thus, genre analysis needs to take into account emic knowledge and ideologies that circulate in, and frame the interpretations of, discourse communities. As discourse has become more visible via digital media, respective data has become increasingly available in the form of metapragmatic discourse this community zealously produces. 
Among other trends, what the observation of such circulations seems to emphasize is that those 'proper' generic labels that genre analysts prefer to draw on (at times simultaneously implying that genres fall into neat types and are feasibly organizable in 'nameable' taxonomies) are just one way to contextualize genres. As we have indicated, such labels may or may not actually be used by the discourse community. On the other hand, what the members of these communities do use is a wide range of other 'imprecise', 'less proper' genre references. This leads us to remind us again, finally, that any generic reference, be it the 'proper' researchcommunity-endorsed label, the genre-like wordings mentioned above or other genre cues, is just part of a small subset of all the metapragmatic devices that are at the disposal of discourse communities, devices that flank and equip their social 'doings' and 'beings' and their pathways through discourse.

(C) Evgeni N. Molodychenko and Jürgen Spitzmüller, 2021
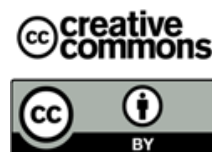

This work is licensed under a Creative Commons Attribution 4.0 International License https://creativecommons.org/licenses/by/4.0/

\section{REFERENCES}

Agha, Asif. 2007. Language and Social Relations. Cambridge: Cambridge University Press. DOI: $10.1017 / \mathrm{CBO} 9780511618284$

Andersen, Thomas Hestbæk \& Theo Jacob van Leeuwen. 2017. Genre Crash: The Case of Online Shopping. Discourse, Context \& Media 20. 191-203. DOI: 10.1016/ j.dcm.2017.06.007

Androutsopoulos, Jannis. 2001. What Names Reveal About the Music Style: A Study of Naming Patterns in Popular Music. In Enikő T. Németh (eds.), Pragmatics in 2000: Selected Papers from the 7th International Pragmatics Conference 2. 16-29. Antwerp: International Pragmatics Association.

Askehave, Inger \& Anne Ellerup Nielsen. 2005. Digital Genres: A Challenge to Traditional Genre Theory. In Ellerup Nielsen Anne, Barbara H Kwaśnik \& Kevin Crowston (eds.), Information Technology and People 18 (2). 120-141. DOI: 10.1108/09593840510601504

Askehave, Inger \& John M. Swales. 2001. Genre Identification and Communicative Purpose: A Problem and a Possible Solution. Applied Linguistics 22 (2). 195-212. DOI: 10.1093/ applin/22.2.195

Auer, Peter. 1992. Introduction: John Gumperz' Approach to Contextualization. In Peter Auer \& Aldo Di Luzio (eds.), The Contextualization of Language (Pragmatics \& Beyond New Series) 22. 1-37. Amsterdam: John Benjamins Publishing Company. DOI: 10.1075/pbns.22

Bell, David \& Joanne Hollows (eds.). 2005. Ordinary Lifestyles: Popular Media, Consumption and Taste. Maidenhead: Open University Press.

Bell, David \& Joanne Hollows (eds.). 2006. Historicizing Lifestyle: Mediating Taste, Consumption and Identity from the 1900s to 1970s. London and New York: Routledge.

Bhatia, Vijay Kumar. 1993. Analysing Genre: Language Use in Professional Settings. London and New York: Longman.

Blommaert, Jan. 2015. Meaning as a Nonlinear Effect: The Birth of Cool. AILA Review 28. 7-27. DOI: 10.1075/aila.28.01blo 
Bolter, Jay David \& Richard Arthur Grusin. 1999. Remediation. Understanding New Media. Cambridge, MA/London: MIT Press.

Boyd, Michael S. 2014. (New) Participatory Framework on Youtube? Commenter Interaction in Us Political Speeches. Journal of Pragmatics 72. 46-58. DOI: 10.1016/j.pragma. 2014.03.002

Briggs, Charles L. 1993. Generic Versus Metapragmatic Dimensions of Warao Narratives: Who Regiments Performance? In John A. Lucy (eds.), Reflexive Language: Reported Speech and Metapragmatics, 179-212. Cambridge: Cambridge University Press. DOI: 10.1017/CBO9780511621031.011

Briggs, Charles L. \& Richard Bauman. 1992. Genre, Intertextuality, and Social Power. Journal of Linguistic Anthropology 2 (2). 131-172.

Bucholtz, Mary \& Kira Hall. 2005. Identity and Interaction: A Sociocultural Linguistic Approach. Discourse Studies 7 (4-5). 585-614. DOI: 10.1177/1461445605054407

Chernyavskaya, Valeria. 2020. Metapragmatics: When the Author Brings Meaning and the Adressee Context. Vestnik Sankt-Peterburgskogo Universiteta. Yazyk i Literatura 17 (1). 135-147. DOI: 10.21638/spbu09.2020.109

Devitt, Amy J. 2009. Re-Fusing Form in Genre Study. In Janet Giltrow \& Dieter Stein (eds.), Genres in the Internet: Issues in the Theory of Genre, 27-48. Amsterdam/Philadelphia: John Benjamins Publishing Company.

Devitt, Amy J. 2015. Genre Performances: John Swales' Genre Analysis and RhetoricalLinguistic Genre Studies. Journal of English for Academic Purposes 19. 44-51. DOI: 10.1016/j.jeap.2015.05.008

Eckert, Penelope. 2008. Variation and the Indexical Field. Journal of Sociolinguistics 12 (4). 453-476. DOI: 10.1111/j.1467-9841.2008.00374.x

Fairclough, Norman. 2003. Analysing Discourse: Textual Analysis for Social Research. London and New York: Routledge.

Giltrow, Janet. 2010. Genre and Difference: The Sociality of Linguistic Variation. In Heidrun Dorgeloh \& Anja Wanner (eds.), Syntactic Variation and Genre, 1-26. Berlin/New York: De Gruyter Mouton.

Giltrow, Janet \& Dieter Stein. 2009. Genres in the Internet. Innovation, evolution, and genre theory. In Janet Giltrow \& Dieter Stein (eds.), Genres in the Internet: Issues in the Theory of Genre, 1-26. John Benjamins Publishing Company. DOI: 10.1075/pbns. 188

Gnezdilova, Yaroslava. 2018. Metapragmatics of Academic Written Discourse. Lege Artis 3. 46-79. DOI: 10.2478/lart-2018-0002

Gumperz, John J. 1992. Contextualization and Understanding. In Alessandro Duranti \& Charles Goodwin (eds.), Rethinking Context: Language as an Interactive Phenomenon, 229-252. Cambridge: Cambridge University Press.

Halliday, Michael A. K. \& Christian M. I. M. Matthiessen. 2004. An Introduction to Functional Grammar. London: Hodder Education.

Hanks, William F. 1987. Discourse Genres in a Theory of Practice. American Ethnologist 14 (4). 668-692. DOI: 10.1525/ae.1987.14.4.02a00050

Hiippala, Tuomo. 2017. An Overview of Research Within the Genre and Multimodality Framework. Discourse, Context and Media 20. DOI: 10.1016/j.dcm.2017.05.004

Ivanova, Svetlana V. 2019. Stylistics and rhetoric of lifestyle discourse. Professional Discourse \& Communication 1 (2). 8-21. DOI: 10.24833/2687-0126-2019-1-2-8-21

Jackman, Henry. 2017. Meaning Holism. In Edward N. Zalta (eds.), The Stanford Encyclopedia of Philosophy. Metaphysics Research Lab, Stanford University. URL: https://plato.stanford.edu/archives/spr2017/entries/meaning-holism/ (accessed: 10 September 2020). 
Lee, David Y.W. 2001. Genres, Registers, Text Types, Domains and Styles: Clarifying the Concepts and Navigating a Path Through the BNC Jungle. Language Learning and Technology 5 (3). 37-72.

Machin, David \& Theo van Leeuwen. 2005. Language Style and Lifestyle: The Case of a Global Magazine. Media, Culture \& Society 27 (4). 577-600. URL" https://doi.org/10.1177/ 0163443705054151 (accessed: 10 September 2020).

Machin, David \& Theo van Leeuwen. 2007. Global Media Discourse: A Critical Introduction. London: Routledge.

Miller, Carolyn. 1984. Genre as social action. Quarterly Journal of Speech 70 (2). 151-167. URL: https://doi.org/10.1080/00335638409383686 (accessed: 10 September 2020).

Molodychenko, Evgeni N. 2019. "Lifestyle Instruction" as an Internet Genre in Consumer Culture: A Communicative-Pragmatic Perspective. Vestnik Tomskogo Gosudarstvennogo Universiteta, Filologiya 57. 79-102. DOI: 10.17223/19986645/57/5.

Rose, David. 2012. Genre in the Sydney School. In James Paul Gee \& Michael Handford (eds.), The Routledge Handbook of Discourse Analysis, 209-225. London and New York: Routledge.

Silverstein, Michael. 1976. Shifters, Linguistic Categories, and Cultural Description. In Keith H. Basso \& Henry A. Selby (eds.), Meaning in Anthropology, 11-55. Albuquerque: University of New Mexico Press.

Silverstein, Michael. 1987. The Three Faces of "Function": Preliminaries to a Psychology of Language. In Maya Hickmann (eds.), Social and Functional Approaches to Language and Thought, 17-38. Orlando: Academic Press.

Silverstein, Michael. 1992. The Indeterminacy of Contextualization: When Is Enough Enough? In Peter Auer \& Aldo Di Luzio (eds.), The Contextualization of Language (Pragmatics \& Beyond New Series), 55-76. Amsterdam: John Benjamins Publishing Company.

Silverstein, Michael. 1993. Metapragmatic Discourse and Metapragmatic Function. In John Arthur Lucy (eds.), Reflexive Language: Reported Speech and Metapragmatics, 33-58. Cambridge: Cambridge University Press. DOI: 10.1017/cbo9780511621031.004

Silverstein, Michael. 2003. Indexical Order and the Dialectics of Sociolinguistic Life. Words and Beyond: Linguistic and Semiotic Studies of Sociocultural Order 23 (3). 193-229. DOI: 10.1016/S0271-5309(03)00013-2

Spitzmüller, Jürgen. 2021. Ideologies of Communication: The Social Link between Actors, Signs, and Practices. In Judith Purkarthofer \& Mi-Cha Flubacher (eds.), Speaking Subjects. Biographical Methods in Multilingualism Research. Clevedon: Multilingual Matters.

Spitzmüller, Jürgen. 2013. Graphische Variation als Soziale Praxis. Berlin, Boston: De Gruyter. DOI: 10.1515/9783110334241. URL: https://www.degruyter.com/view/title/ 304557 (accessed: 10 September 2020).

Spitzmüller, Jürgen. 2015. Graphic Variation and Graphic Ideologies: A Metapragmatic Approach. Social Semiotics 25 (2). 126-141. DOI: 10.1080/10350330.2015.1010323

Spitzmüller, Jürgen \& Ingo H. Warnke. 2011. Discourse as a 'Linguistic Object': Methodical and Methodological Delimitations. Critical Discourse Studies 8 (2). 75-94. DOI: 10.1080/ 17405904.2011 .558680

Swales, John M. 1990. Genre Analysis: English in Academic and Research Settings. 3rd edn. Cambridge: Cambridge University Press.

Swales, John M. 1993. Genre and Engagement. Revue Belge de Philologie et D'histoire 71 (3). 687-698. DOI: 10.3406/rbph.1993.3898 
Szabla, Malgorzata \& Jan Blommaert. 2018. Does Context Really Collapse in Social Media Interaction? Applied Linguistics Review 9 (2). DOI: 10.1515/applirev-2017-0119

Verschueren, Jef. 2000. Notes on the Role of Metapragmatic Awareness in Language Use. Pragmatics 10 (4). 439-456. DOI: 10.1075/prag.10.4.02ver

\section{Электронные ресуры / Internet Resources}

Lehti, Lotta, Johanna Isosävi, Veronika Laippala \& Matti Luotolahti. 2016. Linguistic Analysis of Online Conflicts: A Case Study of Flaming in Smokahontas Comment Thread in Youtube. WiderScreen (1-2). URL: http://widerscreen.fi/numerot/2016-1-2/linguisticanaead-on-youtube/ (accessed: 10 September 2020).

\section{Article history:}

Received: 07 December 2020

Accepted: 22 February 2021

\section{История статьи:}

Дата поступления в редакцию: 07 декабря 2020

Дата принятия к печати: 22 февраля 2021

\section{Bionotes:}

Evgeni N. MOLODYCHENKO is Associate Professor of the Department of Foreign Languages at the Higher School of Economics National Research University. His research interests include discourse studies, genre analysis, media linguistics, metapragmatics, rhetoric and persuasive communication.

\section{Contact information:}

Department of Foreign Languages

Higher School of Economics National Research University 16 Soyuza Pechatnikov Str., St. Petersburg, Russia, 190121 e-mail: emolodychenko@hse.ru

ORCID: 0000-0003-4852-6741

Jürgen SPITZMÜLLER is Professor of Applied Linguistics in the Department of Linguistics at the University of Vienna. His research interests include sociolinguistics, language ideologies/metapragmatics, sociolinguistics of scriptality/multimodality, discourse studies and folk linguistics.

\section{Contact information:}

Department of Linguistics

University of Vienna

Sensengasse 3a, 1090 Vienna, Austria

e-mail: juergen.spitzmueller@univie.ac.at

ORCID: 0000-0001-7213-9173 
Сведения об авторах:

Евгений Николаевич МОЛОДЫЧЕНКО - кандидат филологических наук, доценТ департамента иностранных языков Национального исследовательского университета «Высшая школа экономики». Область его научных интересов - дискурс-анализ, анализ речевых жанров, медиалингвистика, метапрагматика, риторика и персуазивность.

\section{Контактная информация:}

Департамент иностранных языков

Национальный исследовательский университет

«Высшая школа экономики»

190121, Санкт-Петербург, Союза Печатников ул., д. 16

e-mail: emolodychenko@hse.ru

ORCID: 0000-0003-4852-6741

Юрген ШПИЦМЮЛЛЕР - доктор наук, профессор института языкознания Венского университета. Область его научных интересов - социолингвистика, метапрагматика, лингвистические идеологии, мультимодальность и дискурс-анализ.

Контактная информация:

Department of Linguistics

University of Vienna

Sensengasse 3a, 1090 Vienna, Austria

e-mail: juergen.spitzmueller@univie.ac.at

ORCID: 0000-0001-7213-9173 